\title{
Prawdziwa tożsamość Jezusa. Polemika z Gezą Vermesem
}

Od pewnego czasu w kręgach naukowych przybrało na sile niezwykłe zainteresowanie żydowskością Jezusa z Nazaretu, które znalazło swoją kulminację w tzw. nurcie „trzeciego poszukiwania Jezusa historycznego” (Third Quest). Nurt ten sięga swymi korzeniami epoki oświecenia, kiedy starano się zrekonstruować obraz Jezusa historycznego niezależnie od wiary Kościoła (,pierwsze poszukiwanie”), a jednocześnie jest reakcją na „drugie poszukiwanie”, w którym koncentracja na wykazywaniu związku między Jezusem i rodzącym się chrześcijaństwa prowadziła rzekomo do wyrwania Założyciela chrześcijaństwa z jego żydowskiego środowiska. Geza Vermes (urodzony w roku 1924 na Węgrzech) zajmuje w tym gronie uczonych miejsce szczególne. Najpierw dlatego, że otrzymał on katolicką formację i zaraz po II wojnie światowej został wyświęcony na kapłana. Odkrył jednak z biegiem czasu swoje żydowskie korzenie i porzucił katolicyzm na rzecz judaizmu (1957). Z pewnością ważną rolę w tym względzie odegrała wieść o śmierci podczas holocaustu jego rodziców: Ernesta Vermesa i Theresii Riesz, dziennikarza i nauczycielki. Studiował najpierw w Budapeszcie, a potem w Louvain, gdzie w 1953 roku uzyskał stopień doktora teologii na podstawie dysertacji dotyczącej niedawno odkrytych zwojów nad Morzem Martwym. Prowadził wykłady zjudaizmu na uniwersytetach w Newcastle (1957-1965) i Oxfordzie (1965-1994). Zasłynął przede wszystkim jako znawca pism qumrańskich, wydając je w języku angielskim (The Complete Dead Sea Scrolls in English, 1997). Swoje życie opisał w dziele pod bardzo wymownym tytułem: Providential Accidents. An Autobiography (Opatrznościowe przypadki. Autobiografia, 1998). 
Książka Gezy Vermesa Twarze Jezusa, tłum. z ang. Jarosław Kołak, Wydawnictwo Homini, Kraków 2008, 351 s. (w oryginalnej wersji angielskiej: The Changing Faces of Jesus, 2000) stanowi dopełnienie - jak stwierdza autor - jego "trylogii” o Jezusie historycznym: Jesus the Jew. A Historian's Reading of the Gospels (1973; wydanie polskie: Jezus Żyd. Ewangelia w oczach historyka, 2003), Jesus and the World of Judaism (1983) i The Religion of Jesus the Jew (1993); z biegiem czasu zostały jeszcze wydane dwie inne publikacje: The Authentic Gospel of Jesus (2003) i The Passion (2005). Twarze Jezusa obejmują prolog, osiem rozdziałów i epilog. „Moje podejście do studiów nad Jezusem - wyjaśnia uczony - cechuje konkretny punkt widzenia: wyobrażam sobie Nowy Testament nie jako niezależną i autonomiczną kompozycję literacką stojącą poza światem żydowskim, lecz spoglądam nań przez pryzmat ówczesnej cywilizacji judaistycznej, która stanowi równocześnie kontekst pierwotnego Kościoła chrześcijańskiego" (s. 10). Geza Vermes twierdzi, że teologowie chrześcijańscy traktowali przez długie wieki literaturę żydowską jedynie jako „służącą” w odniesieniu do Ewangelii jako „pani”: „Postępowanie, jakie proponuję - zaznacza - jest o wiele bardziej demokratyczne. Obu stronnictwom został przyznany głos, i to głos równy" (s. 11). Mając świadomość, że aramejskie orędzie Jezusa zostało przeszczepione na grunt hellenistyczny, Geza Vermes pragnie odnaleźć „,drogę powrotną do żydowskiego Jezusa” (s. 11). „Postanowiłem - wyjaśnia dalej plan swojego dzieła - rozpocząć od boskiego Chrystusa, a potem podjąć kroki w odwrotnym kierunku, po to, by szukać Jezusa ludzkiego. Tak więc w teologicznym diminuendo przemieścimy się z Everestu Ewangelii św. Jana [...] i z wysokich szczytów listów św. Pawła w kierunku Jezusa, którego wizerunek przechowały gminy judeochrześcijańskie, a więc postaci z tego świata, widocznej na wzgórzach Dziejów Apostolskich i na równinie Ewangelii synoptycznych. Mamy nadzieję, że w końcu uda nam się uchwycić sylwetkę prawdziwego Jezusa, kryjącego się w relacjach Marka, Mateusza i Łukasza" (s. 14). W konsekwencji tytuły rozdziałów są następujące: I. Jan: odmieniec pośród ewangelistów; II. Jezus Jana: postać Mesjasza, czyli Przybysz z niebios; III. Paweł: odmieniec pośród Apostołów; IV. Chrystus Pawła: Syn Boży i powszechny Zbawca ludzkości; V. Jezus Dziejów Apostolskich: Prorok, Pan i Pomazaniec; VI. Jezus Ewangelii synoptycznych: charyzmatyczny uzdrowiciel i nauczyciel 
oraz eschatologiczny wizjoner; VII. Poza Ewangelią: prawdziwy Jezus; VIII. Prawdziwy Jezus u zarania trzeciego tysiąclecia.

Zdaniem Gezy Vermesa Ewangelia według św. Jana tak bardzo różni się od Ewangelii synoptycznych, że mogła zostać zaakceptowana jedynie przez adresatów nie związanych bezpośrednio zJezusem i Jego naocznymi świadkami (s. 33). Stanowi ona zatem efekt mistycznych przemyśleń wykształconego Żyda lub światłego Greka działającego na progu II wieku wśród chrześcijan pochodzących z pogaństwa (s. 20). W czwartej Ewangelii trzy różne portrety Jezusa nakładają się nawzajem na siebie. W oczach swoich współczesnych jest On nauczycielem wygłaszającym „długie, bezładne, pełne powtórzeń i często alegoryczne” mowy (s. 37), prorokiem, obiecanym pomazańcem, królem Izraela, mesjańskim synem Bożym, respektowanym panem i barankiem Bożym (s. 38-53). Sam Jezus prezentuje się jako Syn Człowieczy i Syn w relacji do Boga (s. 54-69). W prologu do tej Ewangelii wizerunek Jezusa przybiera rysy greckie inspirowane pismami Filona Aleksandryjskiego:Jezus jest jednorodzonym Bogiem na łonie Ojca, przychodzącym na ziemię Boskim Logosem, który zbawia świat. Zdaniem Gezy Vermesa, ,wyglądając naprzód poprzez swój mistyczny obiektyw, ewangelista był przekonany, że dostrzegł w tej, odległej już wówczas, osobie żydowskiego nauczyciela Jezusa z Galilei nie tylko zbawiciela rodzaju ludzkiego, lecz także przybysza z niebios, w którym rozpoznał wizerunek oblicza Ojca $(\mathrm{J} 1,18)$ " (s. 73).

Przechodząc do Pawła, Geza Vermes uznaje go za „prawdziwego założyciela chrześcijaństwa" (s. 80) i ocenia tego Apostoła Narodów jako „poetycki i mistyczny geniusz” (s. 94). Nie widział on Jezusa „w ciele" i nie wykazywał żadnego zainteresowania Jego życiem ziemskim. Koncentrował się na Chrystusie ukrzyżowanym i zmartwychwstałym, który objawił mu się pod Damaszkiem i uczynił go misjonarzem pogan. Charakteryzowało go "oczekiwanie królestwa Bożego równocześnie z paruzją, czyli powrotem Chrystusa" (s. 94). Hymn Flp 2, 6-11 stwierdzający równość Chrystusa Jezusa z Bogiem traktowany jest przez uczonego żydowskiego za późniejszy z tej racji, że zawiera elementy gnostyckie i mitologiczne (s. 103-104). Z kolei sformułowanie z Rz 9, 5 zinterpretowane zostaje za pomocą znaku interpunkcyjnego w ten sposób, że doksologia odnosi się nie do Jezusa, lecz do Boga Izraela, ku któremu kierowane są wszystkie inne doksologie i modlitwy w listach Pawła (s. 104-107). 
Zdaniem Gezy Vermesa religijna wizja Pawła nie dorównuje wzniosłością teologii Jana, gdyż Jezus jest Synem Bożym dopiero na mocy zmartwychwstania (Rz 1,4), a w momencie paruzji podporządkuje się Bogu, od którego wcześniej otrzymał władzę (1 Kor 15, 28; s. 107). Apostoł Narodów „zatrzymuje się o krok od ogłoszenia boskości Jezusa” (s. 142); dopiero "autorzy deuteropawłowi robią wszystko, co w ich mocy, by przekroczyć Pawła i sięgnąć w stronę szczytów Jana" (tamże).

Matrycą soteriologii Pawła jest „ofiara Izaaka” (Rdz 22), która według pozabiblijnej literatury żydowskiej miała charakter „samoofiarowania” dorosłego już mężczyzny, dokonała się 15 Nisan i wpływała odkupieńczo na całego Izraela aż do przyjścia Mesjasza (s. 111-113). Paweł szkicuje w swoich listach „misteryjny dramat zbawienia”, w którym kluczowe role odgrywają: ,pierwszy Adam”, ten zraju, który zapoczątkował grzech iśmierć, i „ostatni Adam”, właśnie Chrystus (1 Kor 15, 45). „Chrystus - wyjaśnia Geza Vermes - poniósł śmierć za wszystkich grzeszników (Rz 5, 8), dokonując ich odkupienia i potencjalnego zbawienia. Aby zbawienie to stało się rzeczywistością, potrzebują oni wiary, która poszczególnym osobom udziela zasług odkupienia dokonanego przez Chrystusa. [...] Zmartwychwstanie w oczach Pawła jest bezpośrednim odpowiednikiem krzyża: Pan Jezus został wydany na śmierć za ludzkość i za nią zmartwychwstał (Rz 4,25). Jego powstanie z martwych ujawniło w sposób symboliczny odniesiony przez niego absolutny triumf nad grobem" (s. 115-117).

Sięgając po Dzieje Apostolskie, Geza Vermes przede wszystkim dokonuje rekonstrukcji przepowiadania pierwszych chrześcijan. Jezus jest Panem i Mesjaszem dzięki zmartwychwstaniu, a ci, którzy przyjmą chrzest, otrzymują dar Ducha Świętego (por. Dz 2, 22-38). Dużą rolę $\mathrm{w}$ tym przepowiadaniu odegrała egzegeza Biblii w formie peszeru, który nadawał sens tajemniczym wydarzeniom z życia Jezusa (szczególnie Jego śmierci i zmartwychwstaniu), a także umieszczał działalność Jezusa w kontekście przeznaczenia całego ludu żydowskiego (s. 160-166). Religia pierwszych chrześcijan była „pospolitym judaizmem” (s. 168), „sektą nazarejczyków" (Dz 24, 5), a sami chrześcijanie określali się początkowo jedynie mianem „drogi (Pana)” (Dz 9, 2; 19. 2. 23; 22, 4; 24.14. 22) i jawili się jako ruch charyzmatyczny (s. 176). „Dzieje Apostolskie - stwierdza uczony żydowski - nie zawierają niczego, co mogłoby zostać zinterpretowane jako wskazanie na boskość Jezusa" (s. 186). 
Portret Jezusa w Ewangeliach synoptycznych przyjmuje formę biograficzną. Geza Vermes stara się odtworzyć trzy obrazy Jezusa, a mianowicie: z perspektywy narracji ewangelistów, osób współczesnych Jezusowi i samego nauczania Jezusa. $Z$ tej pierwszej perspektywy jawi się On jako cieśla z Nazaretu, wędrowny herold nieuchronnego nadejścia królestwa Bożego, uzdrowiciel i egzorcysta (s. 194-209). Spośród tytułów, którymi obdarzony jest Jezus w Ewangeliach synoptycznych, w Jego ustach najczęściej występuje „Syn Człowieczy”, zastępujący zwyczajnie zaimek osobowy ,ja” (s. 223). Jeśli chodzi o mesjanizm, reakcja Jezusa „oscylowała pomiędzy brakiem entuzjazmu a zaprzeczeniem" (s. 230). Jedyny przypadek, gdy Jezus przyznaje się do mesjanizmu, mianowicie Mk 14, 62 (pozytywna odpowiedź Jezusa na pytanie arcykapłana), sprawia wrażenie zamierzonego zabiegu redakcyjnego ewangelisty, skoro niektóre odpisy poświadczają wersję bliską ujęciu Mateuszowemu (Mt 26, 64): „Ty powiedziałeś, że ja jestem” (s. 232). Tytuł „syn Boży” ma charakter co najwyżej mesjański, a dwukrotne odniesienie Jezusa do „Syna” albo zdradza Jego niższość wobec Boga (Mk 13,32), albo stanowi część tradycji Janowej (Mk 11, 27; s. 233). Wreszcie tytuł „Pan”, o wyraźnych korzeniach semickich, wyraża respekt ludzi wobec Jezusa jako mistrza i cudotwórcy (s. 237-239). Najbardziej adekwatnym tytułem Jezusa jest określenie „prorok”. „W istocie jednomyślne świadectwo ewangelistów - stwierdza Geza Vermes - nie pozostawia żadnej wątpliwości, że życzliwy lud galilejski uważał Jezusa za proroka. Nie działo się tak ze względu na Jego zdolność nauczania i przepowiadania przyszłości. Rozpowszechnione określenie «prorok Jezus z Nazaretu w Galilei» (Mt 21, 11) opierało się na cudach i znakach Mu przypisanych" (s. 243).

Z nauczania Jezusa wyłania się obraz Żyda wiernego Prawu (por. Mt 5, 18 ; Łk 16, 17). Jego uzdrowienia w szabat były zgodne z przekonaniem rabinów, aby ratować życie. Jego uwagi o czystości pokarmów piętnowały lekceważenie Bożego nakazu dokonujące się już w samym w sercu. Wreszcie Jego „antytezy” z Kazania na Górze radykalizowały, a nie znosiły przepisów Tory (s. 245-249). Niewyczerpane źródło religijności Jezusa stanowiło Jego egzystencjalne postrzeganie Bogajako Ojca (s. 249). „Niezachwiana wiara i zaufanie Bogu - zaznacza Geza Vermes - biblijna emuna, była cechą charakterystyczną Jezusa, ideałem, który głosił i który praktykował. To był duchowy motor dzieła całego Jego życia i mamy mocne 
podstawy, by sądzić, iż był mu wierny do swego ostatniego dnia" (s. 258). Jezus synoptyków jest zatem postacią wyraźnie zakorzenioną w historii, a nie Janowym przybyszem z niebios (s. 260). Nie znaczy to jednak wcale, że Jezus synoptyków całkowicie pokrywa się z Jezusem historycznym. „Najbardziej znaczące cechy synoptycznego portretu Jezusa - wyjaśnia uczony żydowski - cechy charyzmatycznego uzdrowiciela i egzorcysty, nauczyciela i orędownika królestwa Bożego, są zasadniczo zależne od postaci historycznej, którą pozostali autorzy Nowego Testamentu stopniowo ukrywali. Fakt, że Jezusa uwielbiano lub oskarżano jako potencjalnego Mesjasza, rozpoczął złożony proces spekulacji teologicznej, który w ciągu trzech stuleci zakończył się wyniesieniem cieśli z Nazaretu do rangi drugiej osoby Trójjedynego Boga, Trójcy Świętej” (s. 279).

Geza Vermes zgodnie z założeniami nurtu ,trzeciego poszukiwania" (Third Quest) uważa, że odtwarzając środowisko życia Jezusa „możemy uchwycić przebłysk tego, kim był naprawdę" (s. 279). Ówczesna Galilea miała charakter żydowski, aczkolwiek jej religię należy określić mianem „popularnej wersji judaizmu” (s. 288). Szczególną renomą cieszyli się charyzmatyczni święci mężowie, jak na przykład Choni (Oniasz), ukamienowany w 65 roku przed Chrystusem (jego wnukowie Chilkia i Chanan) oraz Chanina ben Dosa żyjący w I wieku w Galilei. Mocą niezwykle ufnej modlitwy wypraszali oni u Boga cuda (np. sprowadzali na ziemię deszcz, uzdrawiali, panowali na złem), a także głosili egzystencjalne nauki moralne i nie przywiązywali się zupełnie do dóbr materialnych (s. 296-309). Zdaniem Gezy Vermesa, Jezus był właśnie taką postacią charyzmatyczną, jednym z wielu żydowskich chasydów, aczkolwiek posiadał także rysy odrębne. Przede wszystkim dysponował On wielką osobowością bezżennego nauczyciela (jak gwiazda wśród aktorów drugoplanowych): „był człowiekiem ze stali i ciepłym zarazem, a przy tym całkowicie oddanym Bogu, którego doskonałość i miłosierdzie polecał naśladować" (s. 319). Następnie pozostawił po sobie niezwykłe bogate przesłanie: „Ewangelia przez Niego głoszona jest ogniem, mocą i poezją, jednym z najwyższych szczytów religijnej kreatywności ludu Izraela" (s. 320-321). Wreszcie jak nikt przedtem opowiadał się za bliskością królestwa Bożego na ziemi: „Ogłaszając nie tylko bliskość, lecz potencjalną i - niejednokrotnie - rzeczywistą obecność królestwa Bożego, okazał się nieporównywalnym charyzmatycznym nauczycielem i religijnym 
nauczycielem” (s. 322). Dlaczego więc zginął? „Gdyby - odpowiada Geza Vermes - nie ponosił odpowiedzialności za awanturę w Świątyni Jerozolimskiej w czasie Paschy, kiedy żydowska tradycja oczekiwała, że objawi się Mesjasz, najprawdopodobniej uszedłby z życiem. Uczynienie niewłaściwej rzeczy w niewłaściwym miejscu i w niewłaściwej porze doprowadziło do tragicznej śmierci Jezusa na rzymskim krzyżu" (s. 328).

Skąd zatem wzięła się chrześcijańska wizja Jezusa? Zdaniem autora Twarzy Jezusa pierwsi chrześcijanie ciągłą skuteczność swej działalności charyzmatycznej i uzdrowicielskiej przypisali mocy imienia Jezusa i za pomocą kategorii zmartwychwstania poczęli opisywać własną wewnętrzną przemianę, której w ten sposób doświadczyli po tragedii Jego ukrzyżowania (s. 221). „Z końcem I wieku - stwierdza Geza Vermes - chrześcijaństwo straciło $\mathrm{z}$ oczu prawdziwego Jezusa [...]. Emigracja ruchu Jezusowego $\mathrm{z}$ Jego rodzimego żydowskiego terytorium do - $\mathrm{w}$ pierwszym rzędzie - greckojęzycznego pogańskiego świata śródziemnomorskiego z kulturą klasyczną w tle nastąpiła w zbyt wczesnym stadium. Cele, idee i styl życia chrześcijaństwa nie miały właściwie czasu, by skrystalizować się i rozwinąć. Glina była miękka i plastyczna; można jej było wciąż z łatwością nadawać dowolny kształt, na jaki garncarz miał ochotę. W rezultacie nowy Kościół, wówczas złożony przeważnie z dawnych pogan, wkrótce utracił swą żydowską tożsamość; co więcej, stopniowo stał się antyżydowski” (s. 329).

Geza Vermes, kończąc swoją książkę, stwierdził: „Dotarłem do punktu, w którym moja rola jako historyka dobiega kresu. Głoszenie kazań nie jest moim zajęciem" (s. 337). Przynajmniej od czasów Hermanna S. Reimarusa (XVIII wiek) uczeni liberalni starają się wykazywać, że Chrystus przepowiadany przez Kościół różni się istotnie od Jezusa historii. Oznaczałoby to, że Kościół - świadomie czy nieświadomie - zniekształcił zupełnie wizerunek Jezusa. Procedura Gezy Vermesa charakterystyczna dla całego nurtu Third Quest polega na "wpasowywaniu” Jezusa w jakiś nurt judaizmu. Uczony żydowski traktuje z podejrzeniem wszystkie pisma Nowego Testamentu, poszukując prawdziwego Jezusa zupełnie poza nimi. Jednakże wbrew własnym zapowiedziom, wcale nie przyznaje równego głosu judaizmowi i pierwotnemu chrześcijaństwu, lecz właśnie zjudaizmu czyni „panią”, a z pierwotnego chrześcijaństwa jedynie „służącą” w procesie rekonstrukcji obrazu Jezusa historycznego. 
Wybitne jednostki, a taką bez wątpienia jest Jezus (także dla Vermesa), nie mogą być mierzone tylko miarą kontekstu (judaizmu), ale także i przede wszystkim za pomocą kryterium oddziaływania na historię (pierwotnego chrześcijaństwa). Im lepiej wykaże się zarówno osadzenie Jezusa w judaizmie, jak i Jego oddziaływanie na pierwotne chrześcijaństwo, tym wiarygodniej odtworzy się historyczny wizerunek tej postaci. Zasadnicza idea Twarzy Jezusa, przechodzenie od Chrystusa Syna Bożego i Odkupiciela świata do Jezusa charyzmatycznego chasyda, zdaje się odzwierciedlać życiową drogę i decyzję węgierskiego Żyda i w tym sensie „przepowiadanie” staje się jednak wyraźnie obecne w tej nastawionej na tropienie „historii” książce.

Z tą kwestią wiąże się kolejna, także natury metodologicznej. Jeśli Jezus traktowany jest jako postać religijna, oznacza to, że w badaniach nad Nim trzeba liczyć się z ograniczonym charakterem metody historyczno-krytycznej. Czy Geza Vermes jako wyznawca judaizmu zgodziłby się na czysto historyczne potraktowanie takich wydarzeń fundacyjnych jego religii, jak na przykład teofania na Synaju? Historyk musi być otwarty na sferę nadprzyrodzoną, nawet jeśli jego narzędzia badawcze z natury rzeczy nie są adekwatne, aby ją zgłębić do końca. Tak właśnie zachowywali się pierwsi słuchacze Jezusa. Na ogół zdumiewali się oni Jego wystąpieniem (por. Mk 1,22) i pytali, kim jest (por. Mk 4, 41), otwierając się w ten sposób na głębię Jego tożsamości. Czy można na przykład przejść obojętnie wobec cudów dokonywanych przez Jezusa, skoro - jak przyznaje Vermes - podobne cuda działy się w Kościele pierwotnym w imię Jezusa i zrodziły wiarę w Jego zmartwychwstanie? Czy więc te cuda nie stanowią jakiegoś znaku niezwykłej tożsamości Jezusa, zważywszy, że zarówno ilościowo, jak i jakościowo różnią się od cudów dokonywanych przez innych Żydów? Jaką więc rolę miał Jezus odegrać w historii judaizmu i świata, skoro Bóg obdarzył Go taką mocą? Bliższa analiza orędzia Jezusa pokazuje, że wiązał On nastanie królestwa Bożego i zbawienie ludzi właśnie ściśle ze swoją osobą. W ten sposób Jego autorytet można najprościej opisać jako stawianie się na równi z Bogiem. Tymczasem Geza Vermes, redukując posłannictwo Jezusa do rangi charyzmatycznego proroka, stara się całą Jego tożsamość wykryć na bazie samych tytułów chrystologicznych poddanych abstrakcyjnej analizie literackiej. W swym postępowaniu zastosował on zasadę „reakcji łań- 
cuchowej”. To znaczy najpierw na bazie kontekstu zredukował Jezusa do poziomu charyzmatyka porównywalnego z Chonim czy Chaniną, następnie na podstawie niestosowania przez Jezusa tytułu „Mesjasz” odrzucił Jego mesjanizm, zanegowany mesjanizm doprowadził go z kolei do pojmowania autodesygnacji „Syn Człowieczy” jako zwykłego zaimka osobowego; wreszcie w świetle dotychczasowych wniosków przypisał absolutne rozumienie tytułu „Syna Bożego" hellenizmowi, a tytuł „Pan” zinterpretował w kategoriach ludzkiego respektu wobec Jezusa.

Niewątpliwą zasługą Gezy Vermesa jest próba silniejszego umieszczenia Jezusa w świecie judaizmu. Także odkrycie i opisanie judaizmu charyzmatycznego zasługuje na uwagę, aczkolwiek mocne wiązanie tego nurtu z Galileą jest już słabo uzasadnione. Prezentacja przedstawicieli judaizmu charyzmatycznego, m.in. Choniego czy Chaniny ben Dosa, opiera się na pismach powstałych kilkadziesiąt czy nawet kilkaset lat po ich śmierci. Tymczasem nietrudno dostrzec, że wizerunek chasydzkich charyzmatyków podlegał historycznym modyfikacjom w duchu polemiki judaizmu z chrześcijaństwem. Według Dawnych dziejów Izraela Józefa Flawiusza (koniec I wieku) Choni (Oniasz) uczynił tylko jeden cud - wymodlił deszcz. Chanina ben Dosa zupełnie nie jest wzmiankowany w pismach Józefa Flawiusza. Z kolei w Misznie (II wiek) nie jawi się on jeszcze jako cudotwórca, dopiero późniejsze relacje rabiniczne zaopatrzone są w jego cuda. Te sporadyczne cuda charyzmatyków żydowskich dokonują się w mocy Boga wypraszanej na modlitwie, a nie jak w przypadku Jezusa - na Jego własne polecenie. Geza Vermes nie był w stanie przekonująco uzasadnić, że Jezus jest właśnie jedynie chasydzkim charyzmatykiem. Sprowadzanie całej niezwykłości Jezusa w gronie charyzmatyków jedynie do Jego wielkiej osobowości ludzkiej jest rażąco redukcyjne. Dlaczego inni charyzmatycy zostali w Talmudzie „zrabinizowani” i w ten sposób uprawomocnieni, a Jezus jawi się jako ten, który zwiódł Izraela na bezdroża? Czy w takim razie rzeczywiście nie dał On podstaw do twierdzenia, że Jego relacja do Boga i Prawa jest inna?

W życiu Jezusa, Jego czynach i słowach znajdują się elementy, z których później w świetle Paschy będzie tworzona chrystologia Kościoła. Geza Vermes słusznie ukazuje rezerwę Jezusa wobec tytułu Mesjasz, ale zaraz potem nie potrafi zrobić użytku z faktu, że tytuł ten od samego początku chrześcijaństwa, także w Kościele nieżydowskim, tak mocno 
przylgnął do Jezusa. Gdyby Jezus negował swój mesjanizm, Jego uczniowie twierdziliby potem, iż został On stracony na bazie całkowicie fałszywych oskarżeń; oni tymczasem głoszą, że jest Mesjaszem, aczkolwiek w innym sensie, niż uważali Jego przeciwnicy. Odnosząc się z kolei do tytułu „Pan”, należy zgodzić się, że obejmował on dość szeroką skalę znaczeniową, łącznie ze wskazaniem na Boga. Nazywanie Jezusa Panem w tym właśnie ostatnim sensie wywodzi się z doświadczenia paschalnego.Jednakże doświadczenie paschalne bazuje na tym, że Jezus pojmował swoją relację do Boga jako wyjątkową. W Ewangeliach synoptycznych nie tylko do Boga zwraca się On „Abba” (Mk 14,36), ale także przynajmniej dwukrotnie (Mt 11, 27 par.; Mk 13, 32 par.) utożsamia się z Synem. Tekstu Mt 11, 27 nie wolno odrzucić - jak to czyni Vermes - tylko dlatego, że przypomina teologię czwartej Ewangelii. Właśnie Ewangelia Janowa stanowi ich „egzegezę". Jezus nie jest Synem Bożym jedynie w sensie mesjańskim, lecz absolutnym (por. np. J 5, 22-38; 6, 44; 7, 16; 8, 16.18), skoro jedynie On „zna” Ojca (,i ten, komu Syn zechce objawić”), a Jego „zna” jedynie Ojciec. Tekst Mk 13, 32 z kolei nie wyraża niższości Jezusa wobec Boga, lecz kenozę (uniżenie) Syna Bożego, który stał się człowiekiem. Zresztą gdyby chrześcijaństwo dokonało deifikacji Jezusa na gruncie hellenizmu, cały ten proces musiałby konsekwentnie doprowadzić także w sposób konieczny do doketyzmu, przed którym Kościół broni się od samego początku. Sam Jezus nie tylko mówił o sobie „Syn”, ale również postępował jako Syn w posiadaniu i objawianiu prawdy o Bogu, w autorytatywnym modyfikowaniu Bożego Prawa, w odpuszczaniu grzechów, w byciu tym, przez którego inni mogli stawać się dziećmi Bożymi i w działaniu z całkowitym posłuszeństwem jako pośrednik na rzecz definitywnego królestwa Bożego. Nawet jeśli historycznie nigdy nie nazwał się wprost jedynym Synem Bożym (zob. J 1, 14. 18; 3, 16. 18), to bezsprzecznie prezentował się jako Syn równy Bogu. Całe to bogactwo chrystologiczne zostało przez Gezę Vermesa sprowadzone do wymiarów egzystencjalno-charyzmatycznych, a nie ontycznych.

Autor Twarzy Jezusa nie ma także racji, gdy twierdzi, że św. Paweł zatrzymuje się tuż przed stwierdzeniem Bóstwa Chrystusa. Hymn Flp 2, 6-11 wyznający równość Chrystusa Jezusa z Bogiem Izraela uznawany jest za przed-Pawłowy, a nie późniejszy. Paweł wielokrotnie nazywa Jezusa Synem Bożym, a wskazując na Jego preegzystencję i posłanie, nie 
pozostawia wątpliwości, o jakie synostwo Boże chodzi - ontyczne, a nie egzystencjalne (por. Rz 8, 3.32; 1 Kor 8, 9; Ga 4, 4). Śladami Boskiego kultu Jezusa w listach Apostoła Narodów są m.in. wczesne modlitwy (np. 1 Tes 3, 11-13; 2 Tes 2, 16-17) i wyznania wiary (np. Rz 10, 9-13). Również cały dramat zbawienia, który Geza Vermes na swój sposób odtwarza, byłby bezsensowny - jak to znakomicie ukazywali Ojcowie Kościoła - gdyby Zbawca nie był jednocześnie i Bogiem, i człowiekiem. W tym kontekście staje się także jasne, że tytuł „Pan” stosowany wobec Jezusa oznacza Jego Bóstwo; tytuł ten w pismach Apostoła Narodów odróżnia osobowo Jezusa od Boga określanego mianem „Ojciec”. Desygnacja „Syn Boży” wyraża bardziej wyjątkową relację Jezusa wobec Boga Izraela w dziele realizacji zbawienia ludzi, natomiast desygnacja „Pan” wskazuje raczej w sensie uzupełniającym na związek zachodzący między Chrystusem i wspólnotą wierzących otaczającą Go Boskim kultem.

Jeśli chodzi wreszcie o czwartą Ewangelię, najnowsze ujęcia jej autorstwa nie wykluczają, że Zebedeusz, ojciec Jana, mógł być kapłanem, skoro po pojmaniu Jezusa pozwolono „umiłowanemu uczniowi” (w przeciwieństwie do Piotra) wejść na „dziedziniec arcykapłana” (J 18, 15). W takim razie nie dziwiłaby ani Janowa znajomość realiów świątyni jerozolimskiej, ani jego wzniosła teologia budowana na podstawie mów Jezusa adresowanych nie do prostego ludu galilejskiego, lecz kręgów intelektualnych Izraela. Bardziej tradycyjne ujęcie dopuszcza wieloetapowy proces powstawania tej Ewangelii i znaczący wpływ redakcyjny uczniów Jana.Jednakże refleksyjna teologia czwartej Ewangelii nigdy nie stanowi wypaczenia, lecz ujawnia w mocy wydarzeń paschalnych tę chrystologię, która implicite jest już obecna w nauczaniu samego Jezusa i wczesnych pismach Nowego Testamentu. Głęboki respekt wobec Jezusa nie pozwalał dobrowolnie modyfikować Jego posłannictwa, lecz je wiernie rozwijać. Chrystologia „odgórna” czwartej Ewangelii staje się zrozumiała i wiarygodna wtedy, gdy wcześniej nie zredukuje się chrystologii „oddolnej” Ewangelii synoptycznych. Geza Vermes natomiast tendencyjnie „obniżył” chrystologięJezusa i konsekwentnie w porównaniu z nią chrystologie św. Pawła czy św. Jana wydały mu się zbyt „,wysokie”, aby je zaakceptować.

Kończąc, należy zauważyć, że zasadniczy problem związany z książką Twarze Jezusa polega na apriorycznym założeniu, że między samorozumieniem Jezusa (dziś stosujemy termin: „chrystologia Jezusa”) 
a chrystologią pism Nowego Testamentu, jak i w ogóle chrystologią Kościoła, istnieje „wielkanocna przepaść”. Wbrew temu założeniu teologia katolicka ukazuje, że pod wpływem światła Paschy, w mocy Ducha Świętego chrześcijanie coraz głębiej wyrażają tożsamość Jezusa, którego ziemską „uniżoną" egzystencję mają wciąż jeszcze żywą w pamięci. Chrystologia Kościoła nie jest więc zdradą Jezusa, lecz pogłębioną refleksją teologiczno-biblijną nad danymi, które Jego pierwsi uczniowie poznali jako naoczni świadkowie. Książka Gezy Vermesa Twarze Jezusa zasługuje na uwagę głównie z tego względu, że upomina się bardziej o żydowski kontekst i wymiar życia Jezusa, a także stanowi wyzwanie dla chrystologii katolickiej, aby nieustannie dbała o swój aspekt racjonalny, czyli apologijny i uzasadniający.

Warszawa-Łomża

KS. MAREK SKIERKOWSKI

\section{Słowa kluczowe}

Jezus, chrystologia, judaizm

\section{Summary}

The authentic identity of Jesus. A polemic against Geza Vermes

The text regards a polemic against Geza Vermes, an Jewish scholar, which was translated into Polish and was entitled Twarze Jezusa (Kraków 2008) presented the historical Jesus as a Palestinian charismatic healer and a teacher of simple religiosity. The first disciples of Jesus transferred his message from its Semitic context to the primarily Greek-speaking pagan Mediterranean world where shortly after he became a divine figure. Beginning with the divine figure of Christ presented in the most recent Gospel, namely the Gospel of John, Geza Vermes goes successively back to earlier accounts of the New Testament in order to reveal finally the allegedly true figure of Jesus hidden beneath the oldest Gospels. In the opinion of Marek Skierkowski the method used by Geza Vermes is not adequate and therefore it leads to so false conclusions.

\section{Keywords}

Jesus, Christology, Judaism 